University of Nebraska - Lincoln

DigitalCommons@University of Nebraska - Lincoln

6-2012

\title{
A Survey of Non-Classical Polyandry
}

Kathrine E. Starkweather

University of Missouri, Columbia, kesc99@mail.missouri.edu

Raymond Hames

University of Nebraska - Lincoln, rhames2@unl.edu

Follow this and additional works at: https://digitalcommons.unl.edu/anthropologyfacpub

Part of the Demography, Population, and Ecology Commons, Family, Life Course, and Society Commons, Gender and Sexuality Commons, Place and Environment Commons, Social and Cultural Anthropology Commons, and the Sociology of Culture Commons

Starkweather, Kathrine E. and Hames, Raymond, "A Survey of Non-Classical Polyandry" (2012). Anthropology Faculty Publications. 50.

https://digitalcommons.unl.edu/anthropologyfacpub/50

This Article is brought to you for free and open access by the Anthropology, Department of at DigitalCommons@University of Nebraska - Lincoln. It has been accepted for inclusion in Anthropology Faculty Publications by an authorized administrator of DigitalCommons@University of Nebraska - Lincoln. 
Published in Human Nature 23:2 (June 2012), pp. 149-172; doi: 10.1007/s12110-012-9144-x

Copyright (c) 2012 Springer Science + Business Media. Used by permission.

Published online June 12, 2012.

This manuscript received the Best Paper by a Student award from the Evolutionary

Anthropology Section of the American Anthropological Association at the

annual meeting in Montreal, November 2011.

\title{
A Survey of Non-Classical Polyandry
}

\author{
Kathrine E. Starkweather \\ Anthropology Department, University of Missouri, 107 Swallow Hall, Columbia, MO 65211, USA
}

Raymond Hames

Anthropology Department, University of Nebraska-Lincoln, Lincoln, NE 68588-0368, USA

Corresponding author - Kathrine E. Starkweather, email kesc99@mail.missouri.edu

\begin{abstract}
We have identified a sample of 53 societies outside of the classical Himalayan and Marquesean area that permit polyandrous unions. Our goal is to broadly describe the demographic, social, marital, and economic characteristics of these societies and to evaluate some hypotheses of the causes of polyandry. We demonstrate that although polyandry is rare it is not as rare as commonly believed, is found worldwide, and is most common in egalitarian societies. We also argue that polyandry likely existed during early human history and should be examined from an evolutionary perspective. Our analysis reveals that it may be a predictable response to a high operational sex ratio favoring males and may also be a response to high rates of male mortality and, possibly, male absenteeism. Other factors may contribute, but our within-polyandry sample limits analysis.
\end{abstract}

Keywords: Polyandry, Pair-bonding, Cross-cultural analysis, Marriage, Operational sex ratio

Social scientists are under the impression that polyandry is rare. In many texts, ranging from introductory anthropology to those on marriage and sexuality, one finds generalizations that polyandry is an exceptionally rare marital form occurring in only four of the 565 societies in Murdock's World Ethnographic Sample (Murdock 1957). Occasionally the figure of seven is given, citing Murdock's 1,167-society Ethnographic Atlas (Murdock 1967). The low incidence of polyandry is frequently echoed in review articles of marriage systems. Reviews by polyandry experts note that there are around 28 polyandrous societies in one classical area, the Tibetan plateau (Peter 1963; Cassidy and Lee 1989), substantially 
more than is normally presented. Knowing that polyandry was practiced among the Yanomamö and Inuit cultures, we decided to search for the literature outside of the core or classical area, and we were able to uncover 53 cases of what we call non-classical polyandry (Starkweather 2010) to distinguish these societies from those commonly mentioned in the area of the Himalaya mountains shared by India, Nepal, and Tibet, as well as the Marquesas Islands in the South Pacific. While the frequency of polyandry as a marriage option in non-classical societies is rarer than in classical societies, these unions are culturally legitimate modes of marriage and are found in every part of the world. Our goal here is to describe the social, demographic, and economic characteristics of non-classical polyandrous societies and, where we can, evaluate some hypotheses of polyandry.

We believe this worthwhile because Murdock (1949:25) influentially said, "polyandry is so infrequent a phenomenon that there is no justification for assigning to it . . . an important place in the evolution of social organization." However, as we shall show, the occurrence of polyandry, especially among egalitarian groups, suggests that it does in fact hold a place in human evolutionary history. Furthermore, its existence and adaptiveness has been debated by evolutionarily informed researchers even though they have focused on what we call classical polyandry (see Hrdy 2005 for an exception).

Until recently, the institution of non-classical polyandry has not been analyzed comparatively. However, with the introduction of the concept of partible paternity, a cultural belief that a child can have more than one biological father, by Beckerman and colleagues $(1998,2002)$ and in Beckerman and Valentine's (2002a) edited volume, there has been increased anthropological interest in the topic. These works and others led Hrdy (2000) to characterize certain partible paternity cultures as having a form of polyandry. More recently Walker et al. (2010) examined 128 South American societies and found 53 with partible paternity beliefs, 23 with singular paternity, and 52 with a lack of information on paternity conceptions. Although Beckerman does not link partible paternity with polyandry, two contributors (Alès 2002; Erikson 2002) to the volume he edited do. In addition, Walker et al. (2010) note the connection between partible paternity and polyandry. In this paper we consider some partible paternity societies to be practicing a form of what we call informal polyandry when two men are socially recognized as sires and provide some investment to the same woman and her child. In general, we define polyandrous unions as a bond of one woman to more than one man in which the woman has relatively restricted sexual rights toward the men, and the men toward the woman, as well as economic responsibilities toward each other and toward any children that may result from the union. Partible paternity societies that meet the above definition are referred to as practicing informal polyandry. The term formal (or residential) polyandry is reserved for those societies that add the dimension of coresidence to the above definition.

\section{Evolutionary Biological Theories of Polyandry}

Biologists commonly distinguish between classical polyandry, when females mate sequentially with different males, and cooperative polyandry, the focus of this paper, when two or more males "form stable social units with a single female" (Heinsohn et al. 2007:1047). Emlen and Oring (1977) suggested that the operational 
sex ratio (OSR) is a significant determinant of polyandry across a wide variety of vertebrates. When the OSR is male-biased, polyandry becomes more likely, and when female-biased, polygyny becomes more likely. In polyandry, the rarer sex (e.g., females in a male-biased population) will be more selective and have greater bargaining power such that males who demonstrate greater parental capabilities or signs of fitness will be selected. However, a number of studies (Janssen et al. 2008) show this view is oversimplified. Cooperative polyandry may arise either because of the benefits of joint male defense of a territory or when a female's territory overlaps with the territories of several males (Heinsohn et al. 2007). Regardless, polyandry coupled with cooperative breeding (care of immatures by non-parents) is found among a variety of canids (Wagner et al. 2007) and other mammals (Hrdy 2005, 2009). As for nonhuman primates, polyandry is well studied among many callitrichids (tamarins and marmosets) (Goldizen 1990; Schaffner and French 2004). In primates, polyandry seems tied to high female reproductive costs through twinning, which requires male investment and/or helpers at the nest to enhance fertility and survivorship. However, in some callitrichids polyandry appears to be facultative: polyandry occurs when group size is small and transitions to monogamy as group size increases, allowing older offspring to serve as alloparents. In these polyandrous groups, male-male competition is attenuated and all have sexual access to the female and care for the unusually large offspring of these species by carrying and safeguarding (Schaffner and French 2004). These primates are cooperative breeders, supporting Hrdy's (2009) suggestion that facultative polyandry is a common corollary of cooperative breeding.

\section{Anthropological Theories of Polyandry}

Westermarck was the first to think productively and comparatively about the determinants of polyandry (Westermarck 1926). He proposed a variety of determinants for polyandry across different types of societies, including skewed sex ratios with males outnumbering females, resource limitations, geographical circumscription, and prolonged absences of husbands from home. Some of these factors have been identified by subsequent researchers as potential causes of polyandry, but analysis has been restricted to cases of classical polyandry (Cassidy and Lee 1989). Below we describe theories that have some currency among researchers.

\section{Monomarital Principle}

One theory that appears numerous times throughout the literature and has been suggested in different ways by several different scholars is the monomarital rule (e.g., Goldstein 1978). Among the classical societies, where land is scarce and a fundamental requirement for successful reproduction and the maintenance of high status, the marriage of all brothers in a family to the same wife allows plots of familyowned land to remain intact and undivided (Cassidy and Lee 1989). If each brother were to marry his own wife and the land were divided to accommodate each couple, this would eventually lead to the creation of minifundia, small farms incapable of supporting a family or maintaining social status. In Europe the social mechanism to prevent minifundias was the impartible inheritance of land through either pri- 
mogeniture or ultimogeniture (Kasdan 1965). This form of impartible inheritance is one of the main purposes of Sri Lankan polyandry (Tambiah 1966). Chandra (1987), Majumdar (1962), Parmar (1975), and Saksena (1962) similarly argue that polyandry in India leads to less land fragmentation, and Goldstein (1978) reports that, among an ethnically Tibetan community in northwestern Nepal, polyandry is practiced to avoid dividing family estates. He argues that this might also help to solidify wealth and class advantages, especially when external economic opportunities are limited (see also Haddix and Gurung 1999; Levine 1990).

\section{Division of Labor and Low Productivity}

Alexander (1974) hypothesized that polyandry is related to low but reliable productivity of farms where men dominate all areas of production. With limitations on land and labor it sometimes requires two men to support a woman and her children.

\section{Skewed Sex Ratio}

In a number of non-classical polyandrous societies a high male sex ratio (high OSR) has been employed to explain the incidence of polyandry (e.g., Peters and Hunt 1975 and Peters 1982 for the Yanomamö; Kjellstrom 1973 for the Inuit). Marlowe (2000:47) makes this assumption in his analysis of marital systems but does not demonstrate its role because of a lack of comparative data. In some cases this shortage of marriageable females is exacerbated by polygyny. In this situation it may be in the interest of a male with low competitive abilities to make the best of a bad situation by becoming a junior husband and having some chance of reproduction. Through time the marriage market may improve, and by working hard the junior husband may be able to demonstrate his attractiveness as a mate to another female and marry her.

\section{Male Absenteeism}

In a number of instances polyandry seems to be an adaptation to long male absences coupled with a fear of wife abduction or unfaithfulness. This is particularly clear in the Inuit literature (e.g., Balikci 1963), where forcible abduction is said to be a widespread concern. Kjellstrom (1973:74-87) discusses murder, abduction, and capture through warfare as means of acquiring wives among Inuit peoples. Faced with the alternative of losing a wife or having one's wife impregnated by an unrelated male, the Inuit, for example, set up formal polyandrous relationships with other males. Most commonly a man's younger brother is selected, creating fraternal polyandry. The possible fitness cost of a brother impregnating one's wife is reduced, since the offspring will minimally be related as a nephew or niece with a coefficient of relatedness of 0.25 (Hamilton 1964). Alternatively, given high male mortality among Inuit men, this arrangement could be a consequence of the father effect explored below.

\section{Father Effect}

Father effect refers here to the consequences for the survival and well-being of a child should the biological father die and is inspired by Beckerman's research on 
partible paternity (Beckerman et al. 1998). Partible paternity often leads to informal polyandry, which we defined earlier. In a number of the societies that believe a child can have more than one father, men who had sex with the mother in the months prior to parturition are identified as fathers and provide paternal investment not only in terms of food but in social and political support as well. Among the Bari, Beckerman et al. (1998) showed that children who had two fathers were significantly more likely to survive to age 15 than children who had one. Similar results were demonstrated for the Ache (Hill and Hurtado 1996).

\section{Is Polyandry an Adaptation?}

There is a theoretical debate between Symons $(1989,1992)$ and Smith (1998) over the evolutionary status of human polyandry and whether it is truly an adaptation. Two issues put forward by Symons concern us: did polyandry exist in the EEA, and is there a psychological mechanism for polyandry? Symons argues that polyandry today is restricted to complex economic formations that did not exist in the EEA, and that although polyandry may be adaptive, it is not an adaptation. His first claim appears to be based on reading the classical literature, in which nearly all cases of polyandry are from stratified agro-pastoralists and agriculturalists inhabiting the Himalayan regions of Tibet, Nepal, and India. While that is for the most part accurate, the data we present below on formal and informal forms of non-classical polyandry indicate that polyandry is found among foragers in a wide variety of environments ranging from the Arctic to the tropics, and to the desert. In fact, as we later show, approximately half of the groups outside of the classical area are hunter-gatherers. If contemporary hunter-gatherers are anything like EEA huntergatherers, it is probable that polyandry has a deep human history.

The second issue is whether there is a specific psychological mechanism underlying polyandry, making such unions adaptations. While we agree with many of the critiques made by Smith (1998) about Symons's requirement of a specific psychological mechanism or mechanisms for polyandry, we argue that there are probable psychological mechanisms that underlie marriage and therefore polyandry. Unfortunately, Symons does not identify the specific psychological mechanisms that underlie any form of marriage. Nevertheless, if we define marriage as a bond between partners predicated on relatively restricted sexual access and cooperative investment in common offspring, then monogamy, polygyny, and polyandry are merely behavioral variants of this kind of bond. It appears that the evolved psychological mechanisms that support the cultural institution of marriage have not been a target of intensive investigation. However, some endocrinologists (Walum et al. 2008) and anthropologists (Fisher 2000; Fisher et al. 2006) are moving towards the identification of such mechanisms.

We argue that marriage (or pair-bonding) is the adaptation. One could speculate that it is the result of several male and female psychological modules sensitive to environmentally determined costs and benefits of different marital forms. For humans, optimal reproduction as well as offspring survivorship and development most of the time requires biparental care. Therefore, one strand of the marriage bond is founded on the coordinated requirement of co-investment in common offspring. Another strand in the bond is paternity certainty. Males are more likely to bond to females if they have reasonable assurance of paternity. Fe- 
males are more likely to bond to males if they are willing to invest in offspring and have good genes. So a mutual commitment to relatively exclusive sex and biparental investment in children leads to the institution of marriage. As with all cooperative behaviors there are conflicts of interest based on the costs of maintaining the marriage and investing in children relative to the possible benefits of seeking other mates.

Finally, Symons (1982:299) asks, "Why should a female be better off with .... three males, each of which invests one-third unit [than] with one male which invests one unit?" He concluded that there is "no evidence that women anywhere normally tie up multiple male parental investments by confusing the issue of paternity." In doing so, Symons (1982) ignores the role of ecological circumstances on mating and parenting strategies. In addition, we do not agree with Symons's assumption that the total investment of three husbands (or co-fathers) would be no greater than that of one. In societies that believe in partible paternity, which we argue is informal polyandry, the secondary husband frequently invests in the child, and if the primary father should die the secondary father often takes more responsibility for the child (Beckerman and Valentine 2002b). These examples clearly contradict Symons's (1982) critique of Hrdy (1981), in which he also suggested that men have evolved to care for a child only when he is very sure of his paternity. As for this issue of paternity confusion, if a man believes through partible paternity that he is a partial father to a child through sexual access to its mother, then investing in a child who may be his may represent a reasonable expenditure of paternal effort, especially if he is not married, his marital prospects are poor, or marriage can only be realized at a future date, or if the child is unlikely to survive the death of the primary father.

\section{Kinds of Polyandry}

As previously stated, we define polyandry as a bond between one woman and more than one man in which the woman has relatively restricted sexual rights toward the men, and the men toward the woman, as well as economic responsibilities toward each other and toward any children that may result from the union. Polyandry takes on different forms throughout the world, and to some extent our distinction between what we call classical and non-classical forms is artificial. The 28 classical societies of the Himalayas and the Marquesas Islands are well known to anthropologists (Cassidy and Lee 1989; Peter 1963). In nearly all of these cases, land is intensively cultivated by men (what Goody (1976) would call a male farming system), large domesticated ungulates and other livestock are important, land is privately held by families, and the social system is stratified. Two additional features of the classical societies stand out in comparison with non-classical polyandrous marriage systems. First, the frequency of polyandrous unions appears to be higher in classical than in non-classical systems. Berreman (1975), Goldstein (1978), and Haddix (2001) document that polyandry can range from $9 \%$ to more than $50 \%$ of all marriages. Data on the frequency of polyandry in non-classical systems are sparse but it seems to occur at a lower incidence than in classical systems. Peters and Hunt (1975:201) report 10 of 15 marriages were polyandrous in 1958 among the Shirishana Yanomamö when the sex ratio was 149. As the population grew and the sex ratio declined to 108 , however, only 1 of 37 mar- 
riages were polyandrous (1975:203). Hames (1992:122) reports 3\% of all married men were in polyandrous unions in a sample of 80 Shamatari Yanomamö marriages. For Yanomamö north of the upper Orinoco, the rate of polyandry appears to be $12 \%$ (Alès 2002:75-79). Second, group marriage or polygynandry (unions in which two or more males have exclusive sexual and domestic relations with two or more women) is commonly found in classical societies (Goldstein 1978) but is absent in all the non-classical cases we investigated

Among the non-classical groups we further distinguish between formal and informal polyandry (Table 1). Formal polyandry is characterized by society-wide recognition of a marital union as legitimate and cohabitation of husbands and wife. In contrast, informal polyandry does not involve marriage or coresidence in the same domicile but necessitates that multiple men were or are simultaneously engaged in sexual relationships with the same woman, that these relationships are recognized and accepted by the local group and a woman's first or primary husband, and that all men in the relationship have socially institutionalized responsibilities to care for the woman and her children. Informal polyandry is often (but not always; see below) found in societies that believe in partible paternity (Beckerman and Valentine 2002b). Partible paternity is the belief that a child can have more than one father because the formation of the fetus is a culmination of multiple acts of sperm deposition. At the time of birth a mother will name a secondary and sometimes a tertiary father as co-fathers to the child. A secondary father is expected to invest in the child through gifts of food and, in some cases (e.g., Ache), may play a more prominent role in the child's life should the primary father die. We classify societies with partible paternity beliefs as informal polyandrous societies so long as two men are socially recognized as co-sires of a child and invest in that common child. One major difference between partible paternity societies practicing informal polyandry and societies with formal polyandry is that sexual relationships with the secondary father may cease after the child is born in partible paternity systems. Although formal polyandry and partible paternity beliefs coexist in some societies, such as the Yanomamö and the Ache, not all cases of informal polyandry involve partible paternity. The most unusual case of non-classical polyandry is the Dieri, a group of hunter-gatherers in Central Australia, in which a man shares his wife with his unmarried tribal brothers, but without cohabitation. According to Howitt (1904), all of these men have sexual rights to the wife and are also responsible for protecting her children.

Table 1. Forms of polyandry

\begin{tabular}{|c|c|c|c|c|c|}
\hline Polyandry type & $\begin{array}{l}\text { Sociopolitical } \\
\text { organization }\end{array}$ & Subsistence & $\begin{array}{l}\text { Rights/ } \\
\text { Responsibilities }^{\dagger}\end{array}$ & Marriage & Cohabitation \\
\hline Classical & State & $\begin{array}{l}\text { Agriculture and } \\
\text { agropastoralism }\end{array}$ & yes & yes & yes \\
\hline $\begin{array}{l}\text { Non-classical } \\
\text { formal }\end{array}$ & $\begin{array}{l}\text { Mostly band } \\
\text { to tribe }\end{array}$ & $\begin{array}{l}\text { Foraging to } \\
\text { horticulture }\end{array}$ & yes & yes & yes \\
\hline $\begin{array}{l}\text { Non-classical } \\
\text { informal }\end{array}$ & $\begin{array}{l}\text { Mostly band } \\
\text { to tribe }\end{array}$ & $\begin{array}{l}\text { Foraging to } \\
\text { horticulture }\end{array}$ & yes & no & no \\
\hline
\end{tabular}

† Rights and responsibilities to mate and offspring; should be institutionalized and implicitly or explicitly recognized by the social group. 
By our definition, not all societies that believe in partible paternity engage in informal polyandry. For example, among the Curripaco of Venezuela (Valentine 2002) partible paternity is recognized but the secondary father has no obligations to the child, nor is he socially recognized as a father. Walker et al. (2010) refer to these cases as "weak partible paternity" societies. We exclude such societies in our comparative analysis.

\section{Methods}

The fifty-three cultures included in this study (Table 2) were found through a variety of means, including searches in the eHRAF; comparative works focusing on polyandry, such as Westermarck (1926), Murdock (1949), Peter (1963), Levine and Sangree (1980), Cassidy and Lee (1989), Beckerman and Valentine (2002a), and Hrdy (2000); along with ethnographic works on polyandry that contained references to polyandry in other societies. We only included cultures in the sample if the ethnographer mentioned at least one known instance of polyandrous unions that fit the definition of polyandry stated above. If an ethnographer mentioned that polyandry was allowed in a particular society, but knew of no contemporary instances, as Endicott and Endicott (2008) noted for the Batek, the society was not included in this study. We also excluded peoples such as the Afghan Hephthalites, who are claimed to practice polyandry on what we judged to be shaky evidence (Kurbanov 2010). Finally, we excluded groups such as those in Israeli kibbutz communities who sometimes practiced polyandry (Spiro 1975) because we felt this was an exceptionally ephemeral phenomenon.

Data were collected on the following variables: type of polyandry, social stratification, partible paternity, type of economy, relationship of co-husbands, sex ratio at birth, adult sex ratio, adult male mortality, prolonged male absence, and male economic contribution. Many have argued (e.g., Levine and Silk 1997) that polyandrous unions are unstable. We could not find sufficient data on this variable in the sources we consulted. Specific decision-making rules were employed when coding each variable, as described below.

Type of Polyandry

The ethnographer's description of the polyandrous unions in each society was used to code this variable. A society was considered to practice formal polyandry if the author indicated that the unions involved marriage between the women and each man in the union. A society was considered to practice informal polyandry if the woman was not married and did not coreside with all of the men in the union who were investing in her and her children.

\section{Social Stratification}

The descriptions of social stratification are fairly straightforward in the literature, and therefore the description of a society's stratification was used to code each case. The coding for this variable is based on Service's (1962) fourfold classification of societies. When the ethnographer indicated that a group is a small, un- 
Table 2. Cultures and sources used in statistical analysis

\begin{tabular}{|c|c|}
\hline Region/Culture & Reference \\
\hline \multicolumn{2}{|l|}{ Africa } \\
\hline !Kung & Lee 1972 \\
\hline Bahuma & Roscoe 1932 \\
\hline Canarians & Bontier et al. 1872 \\
\hline Irigwe & Sangree 1980; Levine and Sangree 1980; Muller 1980 \\
\hline Lele & Tew 1951 \\
\hline Maasai & Hollis 1905; Spencer 1988 \\
\hline \multicolumn{2}{|l|}{ Asia } \\
\hline Gilyaks & Czaplicka 1914 \\
\hline Mongolians & Riazanovskii 1965 \\
\hline Nayar & Gough 1952, 1959 \\
\hline Paliyans & Gardner 1972 \\
\hline \multicolumn{2}{|l|}{ Australia } \\
\hline Dieri & Howitt 1904 \\
\hline \multicolumn{2}{|l|}{ North America } \\
\hline Aleut & Jochelson 1908; Jones 1976; Lantis 1970, 1984 \\
\hline Alutiiq & Davydov et al. 1810; Hrdlicka 1975 \\
\hline Blackfoot & Dempsey 1986 \\
\hline Cherokee & Reid 1970 \\
\hline Copper Eskimo & Damas 1975 \\
\hline Iglulik & Damas 1975 \\
\hline Innu & Lips 1947 \\
\hline Iñupiaq & Burch 1975 \\
\hline Mackenzie River Eskimo & Stefansson 1921 \\
\hline Netsilik & Balikci 1963 \\
\hline Paviotso & Park 1937 \\
\hline Pawnee & Grinnell 1891; Lesser 1930 \\
\hline Point Hope Eskimo & VanStone 1962 \\
\hline Polar Eskimo & Weyer 1959 \\
\hline Pomo & Aginsky 1939 \\
\hline Shoshoni & Steward 1936 \\
\hline Tikerarmiut & Rainey 1947 \\
\hline Tlingit & De Laguna 1972; Krause 1956 \\
\hline Utes & Smith 1974 \\
\hline Yokuts & Gayton 1948 \\
\hline \multicolumn{2}{|l|}{ Oceania } \\
\hline Chuuk & Bollig 1967; Goodenough 1951 \\
\hline Hawaiians & Linnekin 1990 \\
\hline Lamotrek Atoll & Alkire 1965 \\
\hline Malekula & Deacon and Wedgwood 1934 \\
\hline
\end{tabular}


Table 2. Cultures and sources used in statistical analysis (continued)

\begin{tabular}{ll}
\hline Region/Culture & Reference \\
\hline $\begin{array}{l}\text { South America } \\
\text { Ache }\end{array}$ & Hill and Hurtado 1996; \\
& Hill, personal communication 2008, 2010 \\
Aymara & La Barre 1948 \\
Barí & Beckerman et al. 2002 \\
Canela & Crocker 2002 \\
Cashinahua & Kensinger 2002 \\
Cubeo & Goldman 1963; Chernela 2002 \\
Guaja & Cormier 2003; Gomes 1991, 1996 \\
Kulina & Pollock 2002 \\
Mehinaku & Gregor 1985 \\
Panoan Matis & Erikson 2002 \\
Suruí & Laraia 1963 \\
Yanomamö & Peters and Hunt 1975; Alès 2002; Hames, field notes \\
Zo'e & Dutilleux 2007; Cartagenes 2010 \\
Southeast Asia & \\
Bang Chan & Phillips 1965 \\
Punans & Hose et al. 1912 \\
Sakai & Skeat and Blagden 1966 \\
Semang & Schebesta 1954 \\
Subanu & Finley and Churchill 1913 \\
\hline
\end{tabular}

stratified or minimally stratified group with either a band or a tribal-type organization, the society was coded as an egalitarian band or tribe. When the author described the society as tribal and also mentioned the presence of weak stratification based on accumulation of wealth, importance of lineages or cross-cutting sodalities, or the presence of a strong bigman or headman, the society was coded as a stratified tribe. A society described by the ethnographer as a chiefdom, or having hereditary stratification, or if the position of chief is inherited, was coded as a chiefdom. A society classified by the ethnographer as a state-level society, or with a ruler who has a monopoly on the use of physical coercion, a great deal of economic specialization, and stratification based on status that is ascribed at birth, was classified as a state $(1=$ egalitarian band or tribe; $2=$ stratified tribe; $3=$ chiefdom; 4 = state).

\section{Partible Paternity}

If the author used the term "partible paternity" or "multiple paternity," or described the culture's beliefs about paternity in such a way that indicated a belief that more than one man could be the biological father of a child, the society was considered to have partible paternity beliefs. On the other hand, if there was no mention of partible or multiple paternity, or if the author indicated that biological 
paternity was believed to belong to only one man, the society was considered not to have partible paternity beliefs ( $1=$ yes; $2=$ no; $0=$ no information).

Type of Economy

All societies were classified on the basis of food production strategies using the following conventional classifications: hunting and gathering; small-scale slash-and-burn horticulture, supplemented with hunting and gathering; primarily small-scale horticulture; pastoralism; agriculture. The ethnographer's description of a group's economic practices was used to determine which strategy was employed ( 1 =purely hunter-gatherer; $2=$ simple slash-and-burn horticulture; 3 = primarily horticulture; $4=$ pastoralism; $5=$ agriculture; $0=$ no information).

\section{Relationship of Co-Husbands}

The decisions regarding the coding of this variable were based on the ethnographer's descriptions of the social relationships of men within the polyandrous unions. If the author used the term "fraternal" or "adelphic" to describe the polyandry, or indicated that the men in the union were almost always brothers or close relatives (such as father/son, uncle/nephew, or cousins), the society was considered to practice fraternal polyandry and was coded as such. If the author used the term "non-fraternal" when describing the relationship of the men in the union or indicated that the men were not brothers or not closely related, the group was considered to practice non-fraternal polyandry. In some cases, an ethnographer indicated that polyandrous unions sometimes occurred among men who were brothers and sometimes occurred among unrelated men. These types of groups were coded as practicing both fraternal and non-fraternal polyandry $(1=$ fraternal; $2=$ non-fraternal; $3=$ fraternal and non-fraternal; $0=$ no information).

\section{Adult Sex Ratio}

Decision rules for the coding of this variable were based on quantitative sex ratio measures or the ethnographer's assessment of a scarcity of marriageable males or females. When specific ratios were available, a ratio of greater than 100 was coded as male-skewed and a ratio below that number was coded as femaleskewed. If no quantitative data were supplied but the ethnographer reported a shortage of marriageable men or women, then female-skewed or male-skewed ratios were coded, respectively. If no mention of skewing or of one sex or the other having difficulty in finding a mate, then the group was deemed to be nonskewed $(1=$ more males than females; $2=$ not skewed [equal number males and females]; $3=$ more females than males; $0=$ no information).

\section{Adult Male Mortality}

Presence or absence of high adult male mortality was based almost solely on the ethnographers' assessments. If the ethnographer mentioned that adult male mortality was high, it was coded as such. If the ethnographer described adult male 
mortality as low, it was coded as low. If no information was available for this variable, it was indicated in the coding. The only exception was made in the cases of Inuit groups for which the authors made no reference to male mortality, but in which men regularly participated in whaling expeditions. Whaling is known to be an activity that commonly resulted in high mortality rates for those involved and therefore, when whaling was a prominent economic activity, the group was considered to have high adult male mortality ( $1=$ high; $2=$ low; $0=$ no information).

\section{Prolonged Male Absence}

The decision rules for this variable were based on the ethnographer's assessments as well as the activities in which males commonly participated. If the ethnographer stated that males were often away from home for long periods of time or made mention of prolonged male absences, or if the author discussed activities, such as trading, warfare, or other travel, which required men to be away from their families for extended periods of time, prolonged male absence was coded as present. If, however, the author indicated that men were home most of the time or were not commonly or frequently gone from home for more than a few days at a time, prolonged male absence was coded as absent ( $1=$ yes; $2=$ no; $0=$ no information).

\section{Male Economic Contribution}

This variable was coded on a five-point Likert scale based on the ethnographer's description of male economic contribution. Although numeric data are obviously preferred and are occasionally available, the majority of the information simply compares male contributions relative to female contributions. Location on the scale was determined in the following way: 1 indicates that males contribute nothing to the subsistence economy, with females contributing everything, and a case was coded as such if the ethnographer used phrases such as "males contribute nothing," "men are responsible for almost none/very little/hardly any of the economic production," or if male contribution falls between $0 \%$ and $20 \%$; 2 indicates that males contribute less than females but are playing an active role in production, and a case was coded as such if phrases such as "slightly less than females" or "male contribution is low" were used, or if male contribution falls between $20 \%$ and $40 \% ; 3$ indicates that males and females contribute approximately the same amount to the subsistence economy, and a case was coded this way if the author used words such as "equal," "the same amount as," or "approximately the same," or if male contribution falls between $40 \%$ and $60 \%$, which leaves some room for error of estimation or for differing ways of categorizing contribution; 4 indicates that males contribute more than females, but that females still make important contributions, and a case was coded this way if the author used phrases such as "slightly more than females" or "male contribution is high," or if the numerical values indicate that the males are contributing between $60 \%$ and $80 \%$; 5 indicates that males contribute nearly all of the food to the group, and a group was coded this way if phrases such as "everything," "all," "extremely high," or "entire" were used to describe male contribution, or if male contribution falls between $80 \%$ and $100 \%$; 0 was used to code any case in which no information was given regarding male economic contribution. 


\section{Results}

Descriptive Trends in Societies That Permit Polyandry

Our goal in this paper is twofold. The first is to descriptively characterize the nature of those societies in which non-classical polyandry is found in terms of their level of social complexity, subsistence economy, and stability of individual marital unions. The second is to test some of the hypotheses of the determinants of polyandry. The descriptive results show that polyandry in non-classical societies is typically fraternal, most commonly found in egalitarian societies, not necessarily associated with partible paternity, and most common among hunter-gatherers and foraging horticulturalists (Table 3).

Type of polyandry. Formal polyandry is the most common form, representing $73.6 \%$ (39 cases) compared with $26.4 \%$ (14 cases) for informal polyandry (Table 3).

Table 3. Statistical summary of type of polyandry, social stratification, partible paternity, type of economy, male relationship, and prolonged male absence

\begin{tabular}{|c|c|c|}
\hline \multicolumn{2}{|l|}{$\begin{array}{l}\text { Variable } \\
\text { Statistics }\end{array}$} & \multirow{2}{*}{$\begin{array}{l}\text { Univariate } \\
39(73.6 \%)\end{array}$} \\
\hline Type of Polyandry & Formal & \\
\hline$(\mathrm{N}=53)$ & Informal (partible paternity) & $14(26.4 \%)$ \\
\hline \multirow{4}{*}{$\begin{array}{l}\text { Social Stratification } \\
(\mathrm{N}=53)\end{array}$} & Egalitarian band or tribe & $40(75.5 \%)$ \\
\hline & Stratified tribe & $4(7.5 \%)$ \\
\hline & Chiefdom & $7(13.2 \%)$ \\
\hline & State level & $2(3.8 \%)$ \\
\hline \multirow{5}{*}{$\begin{array}{l}\text { Subsistence Economy } \\
(\mathrm{N}=53)\end{array}$} & Hunter-gatherer & $26(49.1 \%)$ \\
\hline & Horticultural/Hunter-gatherer & $18(34.0 \%)$ \\
\hline & Farming & $4(7.5 \%)$ \\
\hline & Pastoralist & $3(5.7 \%)$ \\
\hline & Agriculture & $2(3.8 \%)$ \\
\hline \multirow{3}{*}{$\begin{array}{l}\text { Marriage Form } \\
(\mathrm{N}=36)\end{array}$} & Fraternal & $17(47.2 \%)$ \\
\hline & Non-fraternal & $12(33.3 \%)$ \\
\hline & Both & $7(19.4 \%)$ \\
\hline \multirow{3}{*}{$\begin{array}{l}\text { Adult Sex Ratio } \\
(\mathrm{N}=24)\end{array}$} & More males than females & $18(75 \%)$ \\
\hline & Not skewed & $1(4.2 \%)$ \\
\hline & More females than males & $5(20.8 \%)$ \\
\hline \multirow{6}{*}{$\begin{array}{l}\text { Adult Male Mortality } \\
(\mathrm{N}=36) \\
\text { Male Economic Contribution } \\
(\mathrm{N}=53)\end{array}$} & High & $27(75 \%)$ \\
\hline & Low & $9(25 \%)$ \\
\hline & Less than females & $1(1.8 \%)$ \\
\hline & Equal & $18(34.1 \%)$ \\
\hline & More than females & $14(26.4 \%)$ \\
\hline & Nearly all & $20(37.7 \%)$ \\
\hline \multirow{2}{*}{$\begin{array}{l}\text { Prolonged Male Absence } \\
(\mathrm{N}=35)\end{array}$} & Yes & $23(65.7 \%)$ \\
\hline & No & $12(34.3 \%)$ \\
\hline
\end{tabular}


A binomial test $(p=0.001)$ reveals formal polyandry to be a statistically significant characteristic of non-classical polyandry.

Social stratification. Following Service's scheme, societies were divided into egalitarian (bands and tribes) and stratified (chiefdoms and states). A binomial test with level of significance set at 0.5 revealed that egalitarian societies were significantly more common, with 44 cases $(83 \%)(p=0.00)$.

Partible paternity. Forty-three of the 53 societies $(81.1 \%)$ do not believe in partible paternity, which is a significant difference $(p=0.000)$.

Economic formation. Polyandrous societies are dominated by 26 hunter-gatherer societies (49.1\% of our sample) and 18 (30.8\%) slash-and-burn horticulturalists (or foraging horticulturalists, most of whom, such as the Yanomamö, rely heavily on foraging). When we combine hunter-gatherers with foraging horticulturalists and compare them with agriculturalists, a binomial test $(\alpha=0.5)$ shows that foragers and horticulturalists are significantly more common than agriculturalists $(p=0.000)$.

Marriage form. We attempted to classify each society as having fraternal polyandry, non-fraternal polyandry, or a combination thereof. In 17 cases there was no information on this variable. Of the remaining 36 cases, $17(47.2 \%)$ were fraternal, $12(33.3 \%)$ were non-fraternal, and $7(19.4 \%)$ practiced a combination of fraternal and non-fraternal polyandry. Based on a nonparametric one-tailed chi-square test, these differences were not significant $\left(\chi^{2}=4.167, p=0.074\right)$. When fraternal polyandry was combined with fraternal and non-fraternal polyandry and compared with non-fraternal polyandry, the combination of fraternal and sometimes non-fraternal was not statistically more common than non-fraternal $(p=0.067)$.

\section{Theoretical Tests}

Prolonged male absence, high male productivity, and high male operational sex ratio have been hypothesized to be associated with polyandry in classical societies. We now examine these factors in non-classical polyandrous societies. Beckerman and Valentine (2002b) argue that partible paternity represents a kind of insurance policy whereby a woman can call on a secondary father for the support of their potentially common offspring should the primary father perish. We operationalize this as the high adult male mortality hypothesis and examine it below.

A major limitation of our analysis is that we are looking at trends within polyandrous societies and are unable to evaluate whether these trends exist in a crosscultural sample of polyandrous and non-polyandrous societies. For example, we found an association between male productive labor time and high adult male mortality and polyandry (reported and discussed below). Cross-culturally, however, male productive labor time (Ember 1983) and mortality rates (Kruger and Nesse 2006) are greater than female labor time and female mortality. Nevertheless, if no trends are found in the polyandrous societies we examine, the factors we identify as hypothetical determinants of polyandry are probably not worth pursuing in a more inclusive cross-cultural sample.

Male economic production. According to Alexander (1974), men in polyandrous societies should contribute more to the subsistence economy than women. In $65 \%$ of the cases, men contributed more than women (binomial, $p=0.001$ ). However, as noted above, cross-culturally men contribute more to economic pro- 
duction than women do in $77 \%$ of societies (Ember 1983). Consequently, this hypothesis, while confirmed, merely replicates a trend found cross-culturally and is not specific to polyandrous societies.

Adult male mortality. We were able to collect qualitative assessments of adult male mortality data on 36 societies. Of those, 27 or $75 \%$ had high adult male mortality, with significantly fewer societies, 9 of the 36 (25\%), lacking high adult male mortality, yielding a statistically significant difference (binomial, $p=0.004$ ). But as noted above, male mortality rates exceed female rates in nearly all societies (Kruger and Nesse 2006).

Prolonged male absence. Westermarck (1926) hypothesized that prolonged absence of husbands from home should be a predictor of polyandry, and Lesser (1930) and Tambiah (1966) have shown that this circumstance is indeed found in some classical polyandrous societies. Prolonged male absence was found in 23 cases $(65.7 \%)$ but lack of male absence was found in $12(34.3 \%)$. Based on a binomial test with alpha set at 0.5 , the difference was not significant $(p=0.091)$.

Skewed adult sex ratio. Researchers on classical (Berreman 1962) and non-classical (Peters 1982) societies have suggested a male-skewed adult sex ratio (high OSR) as a possible reason for polyandry. In some cases it appears that a surplus of men is a temporary situation (Peters 1998); in others it appears to be a constant, especially in certain environments (e.g., Arctic). Only 24 societies had data on adult sex ratios, and in 18 of them the adult sex ratios were skewed in favor of males (75\%) with 1 unskewed (4.2\%) and 5 skewed in favor of females $(20.8 \%)$. These differences were significant $\left(\chi_{2}^{2}=19.750, p=0.000\right)$.

\section{Discussion}

There seems to be one clear determinant of non-classical polyandry, a maleskewed operational sex ratio. Adult male mortality also seems to play a role, and prolonged male absence trends in that direction but narrowly missed statistical significance. A male-biased operational sex ratio seems to come in two forms, leading to what we call short-term and long-term polyandry. Short-term polyandry appears to be a consequence of isolation in the context of severe depopulation. Long-term polyandry is a consequence of persistent skewing of the sex ratio and a relatively stable adaption. We elaborate these ideas below.

A good historical example of a temporarily skewed sex ratio leading to shortterm polyandry is found in a paper by Laraia (1963) entitled "Arranjos poliândricos ..." (Polyandrous Arrangements) among the Suruí of the Brazilian Amazon, a group socially and economically much like the better-known Yanomamö. The Suruí suffered severe depopulation at contact, leading to a sex ratio in which marriageable males far exceeded marriageable females. There were 14 men and 7 women, two of whom were menopausal. Laraia chose to call these polyandrous unions "arrangements" and not marriages because polyandry "should be reserved exclusively for the forms of marriage that are socially sanctioned and standardized culturally, involving economic cooperation, cohabitation, and all sexual privileges" (Laraia 1963:72, quoting Cooper 1942). In reading Laraia it is difficult to know how the Suruí fail to achieve this standard, especially since he claims that these unions were accepted by the group. In addition, Suruí had amutehea, an extramarital male sexual partner known to spouses. Interestingly, the off- 
spring in some cases were recognized to have two fathers (Laraia 1963:73), which means they may believe in partible paternity. And although Laraia notes there is no requirement for economic cooperation between a woman and her extramarital lover, cooperation did occur in several cases (Laraia 1963:74). Laraia concludes that polyandrous arrangements were made to avoid male-male conflicts over women and thereby maintain the solidarity of the group.

Some may object that inclusion of a marginal group at the precipice of extinction is unreasonable because it represents an extreme situation. Although extreme and perhaps rare, the example of the Suruí does show that polyandry is a solution quickly embraced by groups with high operational sex ratios and it still meets the basic definition of marriage: relatively exclusive sex among partners and responsibility for the care of their common offspring. We would predict that population growth leading to an equilibration of the sex ratio would cause polyandry to disappear as a marital institution in such groups. This point is made explicitly by Peters (1982) in his analysis of Yanomamö polyandry. When the Xiliana Yanomamö underwent depopulation because of Western diseases, leading to an operational sex ratio strongly in favor of men, polyandry became more common. After population growth led to an equilibration of the sex ratio, polyandry diminished in frequency. Hill (personal communication to KS, 2009) reports a similar trend for the Ache.

A number of factors, such as epidemics (Peters 1982), that are likely contributors to the operational sex ratio imbalance in these societies have been enumerated throughout the literature. Among both the Inuit (Birket-Smith 1929; Jennes 1922; Rasmussen 1931; Weyer 1932) and South American groups (Goldman 1963; Hill and Hurtado 1996; Peters and Hunt 1975), preferential female infanticide has been documented. Smith and Smith (1994) report that for some Inuit groups, such as the Netsilik, childhood sex ratios are as high as 204 boys for every 100 girls, and they attribute these highly skewed ratios to preferential female infanticide. Natural disasters have also led to a shortage of females in some groups (Erikson 2002; Peters 1982), as has warfare and the capture of one group's females by another group (Peters and Hunt 1975).

As we discussed above, a high operational sex ratio is likely associated with polyandry because less socially competitive males may be willing to share a wife and make an attempt at achieving paternity, rather than risk never reproducing. A high operational sex ratio may also result in polyandrous unions because of female preference. Beginning with Guttentag and Secord (1983), researchers have demonstrated that members of the sex that is in shortest supply can better realize their mate preferences since their scarcity puts them in a stronger bargaining position (Stone et al. 2007; Pollet and Nettle 2008). Polyandry in the context of a high operational sex ratio may represent strong female choice for high male investment by having two husbands or multiple fathers.

In early human history it is unclear how common extreme operational sex ratio imbalances were and how long they persisted. Birdsell argues that huntergatherer mating pools seem to encompass at least 500 people (Birdsell 1958, 1968), whereas Binford (2002:224-226) documents the regular occurrence of larger groups, depending on environmental circumstances. In any case, extreme sex ratio imbalances would clearly be more likely to be found among smaller, low-density, and often-isolated groups that tend to be egalitarian, such as those reported in this study. 
Long-term and very high sex ratio skewing is found in many polyandrous societies, especially the Inuit, represented by eight of the cases in our sample. This imbalance is extreme in the younger age classes because of preferential female infanticide but still exists at high levels in the operational (adult) sex ratio (Smith and Smith 1994) in spite of high male mortality through foraging mishaps and male-male conflict. One might expect that this long-term sex ratio imbalance would lead to an elaboration of polyandry, such as preferences for fraternal polyandry, but we find no evidence of this. Interestingly, a relatively common feature in Inuit social life, not found in other societies, is spouse sharing or, in Burch's terms, "co-marriage" (1970:110) (sometimes called wife or spouse exchange). Inuit peoples have a variety of dyadic partnerships between men that are largely independent of kinship, such as seal-sharing, song, wrestling, and trading partnerships. These dyadic, non-kin relationships mark close social ties that appear to help buffer against risk in an environment in which resources may be scarce and close kin may not be able to help. In spouse sharing, reciprocal sexual access is permitted and coresidence is uncommon. In some instances, sexual access occurs for only one day or for a short duration; in others, sexual access recurs periodically. These relationships are expected to last a lifetime, children in the co-marriage group are not permitted to marry, and the couples establish "strong bonds of friendship, mutual aid, and protection" (Burch 1970:110). Among North Alaskan Inuit, most married couples were involved in such relationships (Burch 1970:111). Polyandry in Inuit groups may function in a similar way by helping families deal with risks such as resource stress and high male mortality.

Another interesting feature of Inuit groups is that males produce nearly all of the food, an extreme pattern among hunting and gathering groups. In his comparative study of hunter-gatherers, Marlowe (2003:54) shows that as male food production increases, the frequency of polygyny decreases and monogamy increases. Thus, high male productivity coupled with high male mortality may make polyandry and spouse sharing attractive to Inuit men and women. For women it represents a type of insurance should a husband die. She and her children will still have a provider who is motivated to invest in children that may be his own. This adaptation is identical to the one proposed by Beckerman et al. (1998) for partible paternity. For men it represents a type of insurance for his children should he die: his co-husband will invest in his children after his death. Of course, the main difference between men and women in such unions is that only males pay a premium of lost paternity. But the problem with the insurance argument based on high male productivity is that in the South American groups who practice partible paternity, Walker et al. (2010) found that male food production is not nearly as calorically important as it is among high-latitude foragers.

Levine and Silk (1997) note that polyandry in classical societies is a less stable marital form than monogamy or polygyny, owing to male sexual jealousy. Senior husbands attempt to restrict sexual access of junior husbands, and mounting dissatisfaction of junior husbands leads them to leave when new marital prospects materialize. Our reading of the literature on non-classical polyandry suggests that male sexual jealousy is likewise a major source of marital discord, although the stability of the polyandrous unions relative to monogamy or polygyny is unclear. We attempted to collect marital stability data, but it was too rarely recorded for analysis. In all the societies we have investigated, however, polyandry exists alongside monogamy and sometimes polygyny. This is especially true among the 
well-studied Inuit peoples. In these cultures males supply more than $90 \%$ of the dietary calories and women are responsible for the food processing and clothing manufacture that make hunting possible. Exceptionally great hunters are able to support more than one wife; good hunters can support one wife; and mediocre hunters, or those unwilling or unable to take a wife from another man, share a wife. In such instances co-husbands are making the best of a bad situation and perhaps staying alert for new marital opportunities.

We can broaden the issue of sexual jealousy by asking whether any form of polygamous marriage is without jealousy between co-spouses. Jankowiak et al. (2005) challenge the common perception that women in polygynous unions are just as content as women in monogamous unions. After combing through the Standard Cross-Cultural Sample (Murdock and White 1969) they were able to assemble 69 case studies with information about co-wife conflict and cooperation. They found that sexual and emotional conflicts among co-wives were present in $90 \%$ of the societies, along with conflicts over resources and children. Close friendships among co-wives occur only $25 \%$ of the time in any community. They conclude, "we found women's sexual desire and reproductive interests paramount factors in promoting co-wife conflict" (Jankowiak et al. 2005:95).

What we draw from our study and that of Jankowiak et al. (2005) is that both men and women find it difficult to share a spouse and that the apparent greater stability of polygynous unions is not that men are less satisfied in polyandrous unions and women more satisfied in polygynous unions, but rather that men have the power to abandon unions that do not meet their marital and reproductive needs whereas women typically lack such power (Smuts 1992). It is also clear that when certain ecological conditions are met, men can tame their sexual jealousy and cooperate as co-husbands.

Reflecting on societies with partible paternity, Hrdy $(2000,2005)$ argues that they are an example of cooperative breeding. In a review of the human literature, Kramer (2010:418) defines cooperative breeding as occurring when "nonparental individuals help support offspring who are not their own." (We might also note that some cooperative breeding may involve coercion.) Since polyandry means that males invest in offspring who are not their own, in many cases polyandry is clearly a form of cooperative breeding. Reciprocally, one might ask whether cowives in a polygynous union are engaged in cooperative breeding. The comparative work of Jankowiak et al. (2005) suggests that more often than not the answer is no, but this issue requires further investigation to understand what conditions or forms (e.g., sororal polygyny) lead to co-wife cooperative breeding.

\section{Conclusion}

Polyandry is much more common than the comparative statistical literature in the HRAF reveals. A review of the literature yielded a sample of 53 societies outside of the classical area of northern India, Nepal, and Tibet, and the Marquesas. We found that most polyandrous cultures are small-scale egalitarian societies that produce food through hunting and gathering and horticulture. We examined a number of hypotheses, largely derived from the classical literature, to identify factors associated with polyandry. We found that an imbalanced operational sex ratio in favor of males is the only variable robustly associated with polyandry, 
which is consistent with the avian model of Emlen and Oring (1977). In addition, we found that adult male mortality and male absenteeism may be factors. OSR imbalances may exist in two forms. In the persistent form, imbalanced sex ratios appear to be a chronic fact of life and characteristic of high-latitude cultures in which males produce most of the food and are exposed to environmental traumas in the food quest. Fraternal polyandry may be more likely in such cases. In the other situation, the imbalance seems to be a consequence of extraordinary demographic catastrophes that lead to a short-term sex ratio in favor of men. Regardless of the cause of the imbalance, polyandry seems to be a common cultural response among small-scale groups that do not have formal institutions, such as the military or priesthood, to deal with such an imbalance. These groups are also apparently capable of instituting (and abandoning) fairly high rates of polyandry in a very short time frame.

Polyandry seems to occur as a result of strategizing by both males and females. Males are likely responding to a lack of available women (owing to an imbalanced sex ratio, high rates of polygyny, or other factors) and strategizing to improve their reproductive fitness by attempting to achieve paternity. In essence, where a man's reproductive fitness is concerned, sharing a wife may be better than having no wife at all. Females are responding to what seem to be risky environments (ones in which adult males are likely to die or, in some cases, be absent from home for long periods of time), strategizing to gain protection and provisioning from an additional husband. Both males and females are strategizing to ensure survival and eventual reproduction of their offspring. For a female, the loss of a child can greatly negatively affect her reproductive fitness, whereas males can potentially make up for the loss of a child by quickly inseminating another female. However, if a man is likely to die and therefore lose all opportunity for future reproduction, it would be in his best interest, and that of his wife, to attempt to ensure the survival of his existing offspring. Having a secondary husband or father in place would serve as an insurance policy for both mother and father.

This paper demonstrates the importance of examining polyandry from an evolutionary perspective, contrary to the arguments made by Murdock (1949) and Symons $(1989,1992)$. Given that the majority of the groups in this study are small-scale hunters and gatherers or foraging horticulturalists, and that they are from many different parts of the world and live under varying demographic and ecological conditions, this research suggests that polyandry may have existed throughout human evolutionary history. Non-classical polyandry seems to have occurred as a response to a shortage of women or as a precaution against the loss of a husband or father in an environment in which men's provisioning was critical.

Acknowledgments - We would like to thank Eric Smith, Sarah Hrdy, Rob Walker, Ed Hagen, Mary Shenk, and two anonymous reviewers for providing insightful and corrective comments on an earlier draft of this paper even though we failed to always heed them. We also thank Patricia Draper and Daniel Osborne for comments on the paper when in its initial form as a Master's thesis. Finally, we thank Kim Hill for unpublished details on the Ache polyandry. 


\section{References}

Aginsky, B. W. (1939). Control in the Shanel (Pomo) Tribe. American Sociological Review, 4, 209-216.

Alès, C. (2002). A story of unspontaneous generation: Yanomami male co-procreation and the theory of substances. In S. Beckerman \& P. Valentine (eds.), Cultures of multiple fathers: The theory and practice of partible paternity in lowland South America (pp. 62-85). Gainesville: University Press of Florida.

Alexander, R. D. (1974). The evolution of social behavior. Annual Review of Ecology and Systematics, 5, 325-383.

Alkire, W. H. (1965). Lamotrek Atoll and inter-island socioeconomic ties. Urbana: University of Illinois Press.

Balikci, A. (1963). The Netsilik Eskimo. New York: Natural History Press.

Beckerman, S., Lizarralde, R., Lizarralde, M., Bai, J., Ballew, C., Schroeder, S., et al. (2002). The Bari partible paternity project, phase one. In S. Beckerman \& P. Valentine (eds.), Cultures of multiple fathers: The theory and practice of partible paternity in lowland South America (pp. 27-41). Gainesville: University Press of Florida.

Beckerman, S., Lizzaralde, R., Ballew, C., Sissel, S., Fingelto, C., Garrison, A., et al. (1998). The Bari partible paternity project: Preliminary results. Current Anthropology, 39, 164-167.

Beckerman, S., \& Valentine, P. (eds.). (2002a). Cultures of multiple fathers: The theory and practice of partible paternity in lowland South America. Gainesville: University Press of Florida.

Beckerman, S., \& Valentine, P. (2002b). Introduction: The concept of partible paternity among native South Americans. In S. Beckerman \& P. Valentine (eds.), Cultures of multiple fathers: The theory and practice of partible paternity in South America (pp. 1-13). Gainesville: University of Florida Press.

Berreman, G. D. (1962). Pahari polyandry: A comparison. American Anthropologist, 64, 60-75.

Berreman, G. D. (1975). Himalayan polyandry and the domestic cycle. American Ethnologist, 2, 127-138.

Binford, L. (2002). Constructing frames of reference: An analytical method for archaeological theory building using ethnographic and environmental data sets. Berkeley: University of California Press.

Birdsell, J. (1958). On population structure in generalized hunting and collecting populations. Evolution, 12, 189-205.

Birdsell, J. (1968). Some predictions for the Pleistocene based on equilibrium systems among recent foragers. In R. Lee \& I. DeVore (eds.), Man the hunter (pp. 229-240). Chicago: Aldine.

Birket-Smith, K. (1929). The Caribou Eskimos: Material and social life and their cultural position. Report of the Fifth Thule Expedition 1921-24, 5(1). Copenhagen: Gyldeddalske Boghandel, Nordisk Forlag.

Bollig, L. (1967). The inhabitants of the Truk Islands: Religion, life, and a short grammar of a Micronesian people. New Haven, CT: Human Relations Area Files (Originally published in 1927).

Bontier, P., Le Verrier, J., \& Major, R. H. (1872). The Canarian, or book of the conquest and conversion of the Canarians in the year 1402. London: Printed for the Hakluyt Society.

Burch, E. (1970). Marriage and divorce among North Alaskan Eskimos. In P. Bohannan (ed.), Divorce and after (pp. 152-181). Garden City: Doubleday \& Co.

Burch, E. S. (1975). Eskimo kinsmen: Changing family relationships in northwest Alaska. St. Paul: West.

Cartagenes, R. (2010). Ensaio Sobre os Zoe. Retrieved 5/22/2010, from http://www.amazoe.org.br/ textoreferencia/ensaio livro tupi.pdf

Cassidy, M. L., \& Lee, G. R. (1989). Study of polyandry: A critique and synthesis. Journal of Comparative Family Studies, 20, 1-11.

Chandra, R. (1987). Polyandry in the North-Western Himalayas: Some changing trends. In M. K. Raha \& P. C. Coomar (eds.), Polyandry in India (pp. 130-154). Delhi: Gian.

Chernela, J. M. (2002). Fathering in the Northwest Amazon of Brazil: Competition, Monopoly, and Partition. In S. Beckerman \& P. Valentine (eds.), Cultures of multiple fathers: The theory and practice of partible paternity in lowland South America (pp. 160-177). Gainesville: University Press of Florida.

Cooper, J. M. (1942). Some anthropological publications of 1941. Primitive Man, 15(3/4), 71-74.

Cormier, L. A. (2003). Kinship with monkeys: The Guaja foragers of Eastern Amazonia. New York: Columbia University Press.

Crocker, W. H. (2002). Canela "Other Fathers": Partible paternity and its changing practices. In S. Beckerman \& P. Valentine (eds.), Cultures of multiple fathers: The theory and practice of partible paternity in lowland South America (pp. 86-104). Gainesville: University Press of Florida. 
Czaplicka, M. A. (1914). Aboriginal Siberia, a study in social anthropology. Oxford: Clarendon.

Damas, D. (1975). Demographic aspects of Central Eskimo marriage practices. American Ethnologist, 2, 409-418.

Davydov, G. I., Khvostov, N. A., \& Shishkov, A. S. (1810). Dvukratnoe puteshestvie.

De Laguna, F. (1972). Under Mount Saint Elias: The history and culture of the Yakutat Tlingit. Washington, DC: Smithsonian Institution Press.

Deacon, B., \& Wedgwood, C. H. (1934). Malekula, a vanishing people in the New Hebrides. London: G. Routledge \& Sons.

Dempsey, H. A. (1986). The Blackfoot Indians. Toronto: McClelland and Stewart.

Dutilleux, J. P. (Writer) (2007). “The Zo-é: Nomads from the Amazon." Alexandra Films. Available at http: / / oxfordhumanities.com/products details.php? name=products\&id=37

Ember, C. (1983). The relative decline in women's contribution to agriculture with intensification. American Anthropologist, 85, 285-304.

Emlen, S. T., \& Oring, L. W. (1977). Ecology, sexual selection and the evolution of mating systems. Science, 197, 215-223.

Endicott, K., \& Endicott, K. (2008). The headman was a woman. Denver: Waveland.

Erikson, P. (2002). Several fathers in one's cap: Polyandrous conception among the Panoan Matis (Amazonas, Brazil). In S. Beckerman \& P. Valentine (eds.), Cultures of multiple fathers: The theory and practice of partible paternity in lowland South America (pp. 123-136). Gainesville: University Press of Florida.

Finley, J. P., \& Churchill, W. (1913). The Subanu: Studies of a sub-Visayan mountain folk of Mindanao. Washington, DC: Carnegie Institution of Washington.

Fisher, H. (2000). Lust, attraction, attachment: Biology and the evolution of the three primary emotion systems of mating, reproduction, and parenting. Journal of Sex Education and Therapy, 25, 96-103.

Fisher, H., Aron, A., \& Brown, L. (2006). Romantic love: A mammalian brain system for mate choice. Philosophical Transactions of the Royal Society B: Biological Sciences, 6, 2173-2186.

Gardner, P. M. (1972). The Paliyans. In M. G. Bicchieri (ed.), Hunters and gatherers today (pp. 404450). New York: Holt, Rinehart and Winston.

Goldizen, A. W. (1990). A comparative perspective on the evolution of tamarin and marmoset social systems. International Journal of Primatology, 11, 63-83.

Gayton, A. H. (1948). Yokuts and Western Mono ethnography: Tulare Lake, Southern Valley, and Central Foothill Yokuts. Berkeley: University of California Press.

Goldman, I. (1963). The Cubeo Indians of the Northwest Amazon (Vol. 2). Urbana: University of Illinois Press.

Goldstein, M. C. (1978). Pahari and Tibetan polyandry revisited. Ethnology, 17, 325-337.

Gomes, M. P. (1991). O povo Guaja e as condicoes reais para a sua sobrevivencia. São Paulo: Centro Ecumenico de Documentacao e Informacao.

Gomes, M. P. (1996). Os indios Guaja: Demografia, terra, perspectivas de futuro. Relatorio das pesquisas realizadas. Núcleo de Pesquisa Acadêmica da FAE Centro Universitário.

Goodenough, W. H. (1951). Property, kin, and community on Truk. New Haven: Yale University Press.

Goody, J. (1976). Production and reproduction. Cambridge: Cambridge University Press.

Gough, E. K. (1952). Changing kinship usages in the setting of political and economic change among the Nayars of Malabar. Journal of the Royal Anthropological Institute, 82, 71-87.

Gough, E. K. (1959). The Nayars and the definition of marriage. Journal of the Royal Anthropological Institute, 89, 23-34.

Gregor, T. (1985). Anxious pleasures: The sexual lives of an Amazonian people. Chicago: University of Chicago Press.

Grinnell, G. B. (1891). Marriage among the Pawnees. American Anthropologist, 4, 275-282.

Guttentag, M., \& Secord, P. F. (1983). Too many women? The sex ratio question. Beverly Hills: Sage.

Haddix, K. A. (2001). Leaving your wife and your brothers: When polyandrous marriages fall apart. Evolution and Human Behavior, 22, 47-60.

Haddix, K. A., \& Gurung, J. (1999). "Excess women": Non-marriage and reproduction in two ethnic Tibetan communities of Humla, Nepal. Himalayan Research Bulletin, 19(1), 56-65.

Hames, R. (1992). Variation in paternal care among the Yanomamö. In B. Hewlett (ed.), The father's role: Cultural and evolutionary perspectives (pp. 85-110). Chicago: Aldine de Gruyter.

Hamilton, W. D. (1964). The genetical evolution of social behavior, II. Journal of Theoretical Biology, 7, 17-52.

Heinsohn, R., Ebert, D., Legge, S., et al. (2007). Genetic evidence for cooperative polyandry in reverse dichromatic Eclectus parrots. Animal Behaviour, 74, 1047-1054. 
Hill, K., \& Hurtado, A. M. (1996). Ache life history: The ecology and demography of a foraging people. New York: Aldine de Gruyter.

Hollis, A. C. (1905). The Masai: Their language and folklore. Oxford: Clarendon.

Hose, C., McDougall, W., \& Haddon, A. C. (1912). The pagan tribes of Borneo: A description of their physical, moral and intellectual condition, with some discussion of their ethnic relations. London: Macmillan.

Howitt, A. W. (1904). The native tribes of south-east Australia. London: Macmillan.

Hrdlicka, A. (1975). The anthropology of Kodiak Island. New York: AMS.

Hrdy, S. B. (1981). The woman that never evolved. Cambridge: Harvard University Press.

Hrdy, S. B. (2000). The optimal number of fathers: Evolution, demography, and history in the shaping of female mate preferences. Annals of the New York Academy of Sciences, 907, 75-96.

Hrdy, S. B. (2005). Comes the child before man: How cooperative breeding and prolonged postweaning dependence shaped human potentials. In B. Hewlett \& M. Lamb (eds.), Hunter-gatherer childhoods: Evolutionary, developmental and colonial perspectives (pp. 65-91). Piscataway: Aldine Transaction.

Hrdy, S. B. (2009). Mothers and others. Cambridge: Harvard University Press.

Jankowiak, W., Sudakov, M., \& Wilreker, B. C. (2005). Co-wife conflict and co-operation. Ethnology, $44,81-98$.

Janssen, M. H., Arcese, P., Sloan, M. S., \& Jewell, K. J. (2008). Polyandry and sex ratio in the song sparrow. The Wilson Journal of Ornithology, 120, 395-398.

Jennes, D. (1922). The Life of the Copper Eskimos. Report of the Canadian Arctic Expedition 1913-18, vol. 12. Ottawa: F. A. Ackland.

Jochelson, W. (1908). The Koryak. Leiden: E. J. Brill Ltd.

Jones, D. M. (1976). Aleuts in transition: A comparison of two villages. Seattle: Published for the Institute of Social, Economic, and Government Research, University of Alaska, by the University of Washington Press.

Kasdan, L. (1965). Family structure, migration and the entrepreneur. Comparative Studies in Society and History, 7, 345-357.

Kensinger, K. M. (2002). The dilemmas of co-paternity in Cashinahua Society. In S. Beckerman \& P. Valentine (eds.), Cultures of multiple fathers: The theory and practice of partible paternity in lowland South America (pp. 14-26). Gainesville: University Press of Florida.

Kjellstrom, R. (1973). Eskimo marriage. Stockholm: Nordiska Meseets.

Kramer, K. (2010). Cooperative breeding and its significance to the demographic success of humans. Annual Review of Anthropology, 39, 417-436.

Krause, A. (1956). The Tlingit Indians: Results of a trip to the northwest coast of America and the Bering Straits. Seattle: Published for the American Ethnological Society by the University of Washington Press.

Kruger, D. J., \& Nesse, R. M. (2006). An evolutionary life-history framework for understanding sex differences in human mortality rates. Human Nature, 17, 74-97.

Kurbanov, A. (2010). The Hephthalites: An archaeological and historical analysis. Berlin: Free University.

La Barre, W. (1948). The Aymara Indians of the Lake Titicaca Plateau. Menasha: American Anthropological Association.

Lantis, M. (1970). The Aleut social system: 1750 to 1810. In R. E. Ackerman (ed.), Ethnohistory in southwestern Alaska and the southern Yukon (pp. 139-301). Lexington: University Press of Kentucky.

Lantis, M. (1984). Aleut. In D. Damas (ed.), Arctic: Handbook of North American Indians 5 (pp. 161184). Washington D.C: Smithsonian Institution Press.

Laraia, R. de B. (1963). “Arranjos Poliandricos" na Sociedade Surui. Revista do Museu Paulista, 14, $71-75$.

Lee, R. B. (1972). !Kung Spatial Organization: An ecological and historical perspective. Human Ecology, 1, 125-147.

Lesser, A. (1930). Levirate and fraternal polyandry among the Pawnees. Man, 30, 98-101.

Levine, N. E. (1990). Nyinba polyandry and the allocation of paternity. Journal of Comparative Family Studies, 11, 283-298.

Levine, N. E., \& Sangree, W. H. (1980). Conclusion: Asian and African systems of polyandry. Journal of Comparative Family Studies, 11, 385-410.

Levine, N. E., \& Silk, J. B. (1997). Why polyandry fails: Sources of instability in polyandrous marriages. Current Anthropology, 38, 375-398.

Linnekin, J. (1990). Sacred queens and women of consequence: Rank, gender, and colonialism in the Hawaiian Islands. Ann Arbor: University of Michigan Press. 
Lips, J. E. (1947). Naskapi law: law and order in a hunting society. Transactions of the American Philosophical Society, 37, 379-492.

Majumdar, D. N. (1962). Himalayan Polyandry. London: Asia Publishing House.

Marlowe, F. W. (2000). Paternal investment and the human mating systems. Behavioural Processes, 51, 45-61.

Marlowe, F. W. (2003). The mating system of foragers in the standard cross-cultural sample. CrossCultural Research, 37, 282-306.

Muller, J. C. (1980). On the relevance of having two husbands: Contribution to the study of polygynous/polyandrous marital forms of the Jos Plateau. Journal of Comparative Family Studies, 11(3), 359-369.

Murdock, G. P. (1949). Social structure. New York: Macmillan.

Murdock, G. P. (1957). World ethnographic sample. American Anthropologist, 59, 664-687.

Murdock, G. P. (1967). Ethnographic atlas: A summary. Ethnology, 6, 109-236.

Murdock, G. P., \& White, D. (1969). Standard cross-cultural sample. Ethnology, 8, 329-369.

Parmar, Y. S. (1975). Polyandry in the Himalayas. Delhi: Vikas.

Park, W. Z. (1937). Paviotso polyandry. American Anthropologist, 39, 366-368.

Peter, Prince of Greece. (1963). A study of polyandry. Mouton: The Hague.

Peters, J. F. (1982). Polyandry among the Yanomama revisited. Journal of Comparative Family Studies, 13, 89-95.

Peters, J. F. (1998). Life among the Yanomami. New York: Broadview.

Peters, J. F., \& Hunt, C. L. (1975). Polyandry among the Yanomama Shirishana. Journal of Comparative Family Studies, 6, 197-207.

Phillips, H. P. (1965). Thai peasant personality: The patterning of interpersonal behavior in the village of Bang Chan. Berkeley: University of California Press.

Pollet, T. V., \& Nettle, D. (2008). Driving a hard bargain: Sex ratio and male marriage success in a historical US population. Biology Letters, 4, 31-33.

Pollock, D. (2002). Partible paternity and multiple maternity among the Kulina. In S. Beckerman \& P. Valentine (eds.), Cultures of multiple fathers: The theory and practice of partible paternity in lowland South America (pp. 42-61). Gainesville: University Press of Florida.

Rasmussen, K. (1931). The Netsilik Eskimos. Report of the Fifth Thule Expedition 1921-24, vol. 8. Copenhagen: Gyldeddalske Boghandel, Nordisk Forlag.

Rainey, F. G. (1947). The whale hunters of Tigara. Anthropological Papers of the AMNH 41(2). New York. Available online at http:/ / digitallibrary.amnh.org/dspace/handle/2246/125

Reid, J. P. (1970). A law of blood: The primitive law of the Cherokee nation. New York: New York University Press.

Riazanovskii, V. A. (1965). Fundamental principles of Mongol law. London: K. Paul, Trench, Trübner \& Co.

Roscoe, R. C. J. (1932). Immigrants and their influence in the Lake Region of Central Africa. In W. R. Dawson (ed.), The Frazer lectures, 1922-1932 (pp. 25-46). London: Macmillan.

Saksena, R. N. (1962). Social economy of a polyandrous people. London: Asia Publishing House.

Sangree, W. H. (1980). The persistence of polyandry in Irigwe, Nigeria. Journal of Comparative Family Studies, 11, 335-343.

Schaffner, C. M., \& French, J. A. (2004). Behavioral and endocrine responses in male marmosets to the establishment of multimale breeding groups: Evidence for non-monopolizing facultative polyandry. International Journal of Primatology, 25, 709-732.

Schebesta, P. (1954). The Negritos of Asia. Wien-Modling: St. Gabriel-Verlag.

Service, E. R. (1962). Primitive Social Organization: An evolutionary perspective. New York: Random House.

Skeat, W. W., \& Blagden, C. O. (1966). Pagan races of the Malay Peninsula. New York: Barnes \& Noble.

Smith, A. M. (1974). Ethnography of the Northern Utes. Santa Fe: Museum of New Mexico Press.

Smith, E. A., \& Smith, S. A. (1994). Inuit sex-ratio variation: Population control, ethnographic error, or parental manipulation? Current Anthropology, 35, 595-624.

Smith, E. (1998). Is Tibetan polyandry adaptive? Methodological and metatheoretical analyses. Human Nature, 9, 225-261.

Smuts, B. (1992). Male aggression against women: An evolutionary perspective. Human Nature, 3, $1-44$.

Spencer, P. (1988). The Maasai of Matapato: A study of rituals of rebellion. Bloomington: Indiana University Press in association with the International African Institute, London.

Spiro, M. E. (1975). Kibbutz: Venture in utopia. Cambridge: Harvard University Press. 
Starkweather, K. (2010). Exploration into human polyandry: An evolutionary examination of the nonclassical cases. MA thesis, Department of Anthropology, University of Nebraska-Lincoln, Lincoln, Nebraska; online at http:// digitalcommons.unl.edu/anthrotheses/6/

Stefansson, V. (1921). The friendly Arctic: The story of five years in Polar regions. New York: Macmillan.

Steward, J. H. (1936). Shoshoni polyandry. American Anthropologist, 38, 561-564.

Stone, E. A., Shackelford, T. K., \& Buss, D. M. (2007). Sex ratio and mate preferences: A cross-cultural investigation. European Journal of Social Psychology, 37, 288-296.

Symons, D. (1982). Another woman that never existed. Quarterly Review of Biology, 57, 297-300.

Symons, D. (1989). A critique of Darwinian anthropology. Ethology and Sociobiology, 10, 131-144.

Symons, D. (1992). On the use and misuse of Darwinism in the Study of Human Behavior. In J. Barkow, L. Cosmides, \& J. Tooby (eds.), The adapted mind: Evolutionary psychology and the generation of culture (pp. 137-159). Oxford: Oxford University Press.

Tambiah, S. J. (1966). Polyandry in Ceylon. In C. von Fuhrer-Haimendorf (ed.), Caste and kin in Nepal, India and Ceylon (pp. 264-358). London: Asia Publishing House.

Tew, M. (1951). A form of polyandry among the Lele of the Kasai. Journal of the International African Institute, 21, 1-12.

Valentine, P. (2002). Fathers that never exist: Exclusion of the role of shared father among the Curripaco of the northwest Amazon. In S. Beckerman \& P. Valentine (eds.), Cultures of multiple fathers: The theory and practice of partible paternity in lowland South America (pp. 178-191). Gainesville: University of Florida Press.

VanStone, J. W. (1962). Point hope, an Eskimo village in transition. Seattle: University of Washington Press.

Wagner, A. P., Creel, S., Frank, L. G., \& Kalinowski, S. T. (2007). Patterns of relatedness and parentage in an asocial, polyandrous striped hyena population. Molecular Ecology, 16, 4356-4369.

Walker, R. S., Flinn, M. V., \& Hill, K. R. (2010). Evolutionary history of partible paternity in lowland South America. Proceedings of the National Academy of Sciences USA, 107, 195-200.

Walum, H., Westberg, L., Henningsson, S., Neiderhiser, J. M., Reiss, D., Igl, W., et al. (2008). Genetic variation in the vasopressin receptor 1a gene (AVPR1A) associates with pair-bonding behavior in humans. Proceedings of the National Academy of Sciences USA, 105, 14153-14156.

Westermarck, E. (1926). A short history of marriage. New York: Macmillan.

Weyer, E. M. (1932). The Eskimos: Their environment and folkways. New Haven: Yale University Press.

Weyer, E. M. (1959). Primitive peoples today. Garden City: Doubleday.

우

Kathrine Starkweather received her MA in anthropology from the University of Nebraska-Lincoln and is currently a PhD student at the University of Missouri. She traveled to Bangladesh in the fall of 2011 to conduct research among the Shodhagor river gypsies. Her interests include mating, marriage, and parental investment.

Raymond Hames received his PhD in 1978 from the University of California Santa Barbara. He is currently a professor and chair of the Department of Anthropology at the University of Nebraska-Lincoln. As a behavioral ecologist his interests include the flow of goods and services in tribal societies, cooperation, offspring investment, and marriage. 